\title{
PENGARUH PEMAHAMAN KURIKULUM, IKLIM KERJA, DAN MOTIVASI TERHADAP KINERJA GURU PADA SMK YPM 12 TUBAN
}

\author{
Emi Fahrudi
}

STIT Makhdum Ibrahim Tuban

emifahrudi@stitmatuban.ac.id

Akhmad Zaini

STIT Makhdum Ibrahim Tuban

akhmadzaini@stitmatuban.ac.id

\begin{abstract}
Abstrak
Kajian dalam penelitian ini, berusaha menjawab terkait bagaimana hubungan pengaruh pemahaman kurikulum, iklim kerja, dan motivasi kinerja guru yang bekerja di sekolah SMK YPM 12 Tuban. Selain itu, dalam penelitian ini, menjelaskan ada serta tidaknya pengaruh kurikulum terhadap kinerja guru. Hasil dalam penelitian ini, menjelaskan adanya pengaruh yang signifikan motivasi kerja, iklim kerja, terhadap kinerja guru di sekolah SMK YPM 12 Tuban.

Kata kunci: Pemahaman Kurikulum, Iklim kerja, Motivasi dan Kinerja Guru.
\end{abstract}

\section{PENDAHULUAN}

Membahas terkait pendidikan, hal yang dibahas terutama mengenai faktorfaktor yang mempengaruhi kinerja guru yang sangat berpengaruh terhadap hasil pendidikan. Menurut Gibson (1995:56) dalam Suharsaputra (2010:147) bahwa kinerja seseorang dalam menjalankan peran dan fungsinya dipengaruhi oleh tiga kelompok variabel, yakni; variabel individu, variabel organisasi, serta variabel psikologis. Pendapat tersebut di atas menggambarkan bahwa faktor-faktor yang mempengaruhi kinerja seseorang adalah faktor individu dengan karakteristik psikologisnya yang khas, dan faktor organisasi berinteraksi dalam suatu proses yang dapat mewujudkan suatu kualitas kerja dalam suatu lingkungan kerja seseorang tersebut.

Ketiga kelompok variabel tersebut berpengaruh terhadap perilaku kerja dan kinerja yaitu variabel individu, yang meliputi: kemampuan dan keterampilan, latar belakang keluarga, tingkat sosial, pengalaman, umur, etnis, jenis kelamin; selanjutnya adalah variabel organisasi, yang mencakup antara lain: sumber daya, 
kepemimpinan, imbalan, struktur, desain pekerjaan; serta variabel psikologis, yang meliputi: presepsi, sikap, kepribadian, belajar, dan motivasi.

Hal yang mendasar dalam penelitian ini untuk menyikapi fenomena pergantian kurikulum pendidikan setiap terjadi pergantian kabinet. Berkaitan dengan isu tersebut, menurut penulis ini sangat menarik untuk diteliti, maka penulis mengangkat sebuah judul pengaruh pemahaman kurikulum, iklim kerja, dan motivasi terhadap kinerja guru pada SMK YPM 12 Tuban.

Tujuan dalam penelitian ini, untuk menemukan, mengembangkan dan menguji kebenaran suatu pengetahuan. Menemukan berarti berusaha mendapatkan sesuatu untuk mengisi kekosongan atau kekurangan-kekurangan. Mengembangkan berarti memperluas serta mengali lebih dalam apa yang sudah ada (Sutrisno, Hadi, 1997:3).

\section{A.Teori Iklim Kerja}

Kinerja merupakan suatu kegiatan yang dilakukan untuk melaksanakan, menyelesaikan tugas dan tanggung jawab sesuai dengan tujuan yang telah ditetapkan. Dilihat dari arti kata kinerja berasal dari kata performance. Kata “performance” memberikan tiga arti yaitu : (1) "presentasi" seperti dalam konteks atau kalimat "high performance car", atau "mobil yang sangat cepat" ; (2) “pertunjukan” seperti dalam konteks atau kalimat "folk dance performance”, atau "Pertunjukan tari-tarian rakyat"; (3) "pelaksanaan tugas" seperti dalam konteks atau kalimat “in performing his/her duties”(Ruki, 2002 : 14).

Kinerja lebih sering disebut dengan presentasi yang merupakan 'hasil' atau 'apa yang keluar' (outcomes) dari sebuah pekerjaan dan kontribusi sumber daya manusia terhadap organisai. Dalam sebuah perusahaan, menurut Mutis maka persoalan kinerja yang dapat diidentifikasi dari beberapa sudut diantaranya yakni; pertama, Perusahaan yang harus dapat menghasilkan barang atau jasa dengan kualitas yang semakin meningkat; kedua, pelayanan kepada konsumen makin cepat dan makin efisien; ketiga, penekanan biaya produksi sehingga harga pokok penjualan dapat stabil sehingga dapat dirasakan oleh seluruh konsumen; dan keempat, peningkatan pengetahuan dan ketrampilan para pekerja agar dapat 
berinovasi dalam memenuhi kebutuhan konsumen yang selalu berubah menyesuaikan dengan dinamika dan tuntunan zaman (Mutis, 1995: 42-43).

Bila diaplikasikan dalam aktivitas pada lembaga pendidikan berdasarkan pendapat di atas, maka pernyataan kinerja yang dimaksud adalah : (1) presentasi kerja pada penyelenggara lembagga pendidikan dalam melaksanakan program pendidikan maupun menghasilkan lulusan atau output yang semakin meningkat kualitsanya; (2) mampu memperlihatkan atau mempertunjukkan kepada masyarakat (hal ini peserta didik berupa pelayanan yang baik); (3) biaya yang harus dikeluarkan masyarakat untuk "menitipkan" anaknya sebagai peserta didik dalam memenuhi kebutuhan beljarnya tidak memberatkan dan terjangkau oleh seluruh masyarakat; dan (4) dalam melaksanakan tugasnya para pengelola lembaga pendidikan seperti kepala madarasah guru dan tenaga kependidikanya semakin baik dan berkembang serta mampu mengikuti dinamika kebutuhan masyarakat yang selalu berubah sesuai dengan kemajuan dan tuntutan zaman.

Berdasarkan pendapat-pendapat di atas dapat disimpulkan bahwa kinerja adalah hasil kerja yang telah dicapai oleh seseorang dalam suatu organisasi untuk mencapai tujuan berdasarkan atas standardisasi atau ukuran dan waktu yang disesuaikan dengan jenis pekerjaanya dan sesuai dengan norma dan etika yang telah ditetapkan. Teori yang dikemukakan Husanker menyatakan bahwa : "kinerja $=$ ability $\mathrm{X}$ motifasi. Ability $=$ aptitude $\mathrm{X}$ training $\mathrm{X}$ resources. Motivation $=$ desire X commitmetment" (Usman, 2008: 145). Dengan demikian, kinerja = aptitude $\mathrm{X}$ training $\mathrm{X}$ resources $\mathrm{X}$ desire $\mathrm{X}$ commitmetment. Dalam penelitian ini training yang dimaksudkan dalam kajian berupa kemampuan terhadap pemahaman kurikulum, sumber daya adalah suasana iklim kerja, dan komitmen terkandung dalam usaha untuk memahami dengan sungguh-sungguh kurikulum.

Banyak faktor yang mengaruhi mutu kinerja seseorang antara lain: "(1) partisipasi SDM, (2) pengembangan karir, (3) komunikasi, kesehatan dan keselamatan kerja, (4) penyelesaian konflik, (5) insentif yang baik, dan (6) kebanggaan" (Cascio dalam Nawai, 2000: 244). Aspek-aspek lain yang dapat digunakan untuk menilai kinerja atau prestasi kerja diantaranya: (1) kemampuan kerja, (2) kerajinan, (3) disiplin, (4) hubungan kerja, (5) prakarsa, (6) 
kepemimpinan atau hal-hal khusus sesuai dengan bidang dan level pekerjaan yang dijabatnya.

Berkaitan dengan penelitian ini, penulis menggunakan kerangka pikir teori kinerja yang dikemukakan oleh Gibson. Menurut Gibson (1995:56) dalam Suharsaputra (2010:147) bahwa kinerja seseorang dalam menjalankan peran dan fungsinya dipengaruhi oleh tiga kelompok variabel, yakni; pertama, variabel individu. Kedua, variabel organisasi, serta ketiga, variabel psikologis. Dalam kaitan dengan penelitian ini variabel individu meliputi: kemampuan dan ketrampilan (mental dan fisik), latar belakang (keluarga, tingkat sosial, pengalaman), demografis (umur, etnis, jenis kelamin). Variabel organisasi meliputi: sumber daya, kepemimpinan, imbalan, struktur, desain pekerjaan. Variabel psikologis individu meliputi: persepsi, sikap, kepribadian, belajar, motivasi, kepuasan kerja, iklim kerja.

Variabel individu dikelompokkan pada sub-variabel kemampuan dan ketrampilan, latar belakang dan demografis. Sub-variabel kemampuan dan ketrampilan merupakan faktor utama yang mempengaruhi perilaku dan kinerja individu. Variabel demografis, mempunyai efek tidak langsung pada perilaku dan kinerja individu. Variabel psikologik terdiri dari sub-variabel persepsi, sikap, kepribadian, belajar, dan motivasi. Variabel ini banyak dipengaruhi oleh keluarga, tingkat sosial pengalaman kerja sebelumnya dan variabel demografis. Variabel psikologis seperti presepsi, sikap, kepribadian, dan belajar merupakan hal yang komplek dan sulit diukur. Variabel organisasi berefek tidak langsung terhadap perilaku dan kinerja individu. Variabel organisasi digolongkan dalam sub-variabel sumber daya, kepemimpinan, imbalan, struktur, dan desain pekerjaan.

Menurut Spencer and Spencer yang dikutip oleh Idawati (2004:5), ada lima jenis kompetensi, yaitu: Pertama, Knowledge. ilmu yang dimiliki Individu dalam bidang pekerjaan atau area tertentu; Kedua, Skill. Kemampuan untuk unjuk kinerja fisik ataupun mental; Ketiga, Self Concept. Sikap Individu, nilai-nilai yang dianut citra diri, Keempat, Traits. Karakteristik fisik dan respon yang konsisten atas situasi atau informasi tertentu; Kelima, Motives. Pemikiran atau niat dasar konstan dan mendorong individu untuk bertindak atau berperilaku tertentu. Skill dan knowledge seringkali disebut sebagai hard competence, sedangkan 
kompetensi self concept, traits, dan motives disebut soft competence. Terdapat kesamaan antara teori Gibson dan pendapat dari Spencer and Spencer tentang faktor utama yang mempengaruhi kinerja individu berkaitan dengan kompetensi yang harus dimiliki oleh individu, yaitu: kompetensi pengetahuan/kemampuan, kompetensi keterampilan atau keahlian dan kompetensi motivasi.

Berkenaan dengan kepentingan penilaian terhadap kinerja guru. Georgia Departemen of Education telah mengembankan teacher performance assessment instrument yang kemudian dimodifikasi oleh Depdiknas menjadi alat penilaian kemampuan guru (APKG). Alat penilaian kemampuan guru, meliputi: (1) Rencana Pembelajaran (Teaching Plans and Material) atau disebut RPP (rencana pelaksanaan pembelajaran), (2) Prosedur Pembelajaran (Classroom Procedure), dan hubungan antar pribadi Interpersonal Skill), dan indikator penilaiaan terhadap kinerja guru dilakukan terhadap kegiatan pembelajaran di kelas yaitu: (1) perencanaan program kegiatan pembelajaran, (2) pelaksanaan kegiatan pembelajaran, (3) evaluasi atau penilaian pembelajaran. Serta juga abilitas guru, dimana abilitas adalah faktor penting dalam meningkatkan produktifitas kerja, abilitas berhubungan dengan pengetahuan dan ketrampilan yang di miliki individu (Bob Davis, 1994: 235).

\section{B.Teori Pemahaman Kurikulum}

Pemahaman merupakan kemampuan mengetahui dan mengingat sesuatu dari berbagai aspek, karena menurut Sudijono, pemahaman (comprehension) adalah kemampuan seseorang untuk mengerti atau memahami sesuatu setelah sesuatu diketahui dan diingat. Dengan kata lain, memahami adalah mengetahui tentang sesuatu dan dapat melihatnya dari berbagai sisi. Seorang peserta didik dikatakan memahami sesuatu apabila ia dapat memberikan penjelasan atau uraian yang lebih rinci tentang hal itu dengan menggunakan kata-katanya sendiri (Sudijono, 1998: 51).

Kurikulum yang dilaksanakan pada lembaga pendidikan mengacu kepada teori-teori kurikulum yang dikembangkan. Menurut Sukmadinata, teori mengenai kurikulum pada dasarnya kajiannya meliputi hal-hal yang berkaitan dengan penentuan keputusan, penggunaan, perencanaan, pengembangan, evaluasi 
kurikulum, dan lain-lain, (Sukmadinata, 2004: 27). Pada dasarnya teori kurikulum dibedakan menjadi: "1) teori kurikulum, 2) teori kurikulum formal, 3) teori kurikulum valuansional, dan 4) teori kurikulum prasikologi" (Sukmadinata, 2000:31). Dari teori-teori kurikulum di atas dapat dijelaskan sebagai berikut:

Teori kurikulum merupakan teori yang menguraikan dan pemisahan kejadian atau peristiwa kurikulum atau yang berhubungan dengan kurikulum dan yang bukan. Teori kurikulum formal memusatkan perhatiannya pada setruktur isi kurikulum. Kurikulum valuansional mengkaji masalah-masalah pembelajaran apa yang berguna atau berharga bagi keadaan sekarang. Teori kurikulum prasikologi merupakan suatu pengkajian tentang proses untuk mencapai tujuan-tujuan kurikulum" (Sukmadinata, 2007:98).

Kurikulum bukan hanya merupakan rencana tertulis dari pembelajaran, melainkan sesuatu yang fungsional yang beroperasi dalam kelas, yang memberi pedoman dan mengatur lingkungan dan kegiatan yang berlangsung di dalam kelas. Guru yang melaksanakan pembelajaran di lembaga pendidikan formal madrasah pada dasarnya melaksanakan kurikulum tertulis yang tersusun secara sistematis, jelas dan rinci. Dengan berpedoman pada kurikulum, interaksi pendidikan guru dan peserta didik berlangsung.

\section{C.Teori Iklim Kerja}

Iklim kerja disekolah atau madrasah adalah keadaan sekitar sekolah atau madrasah serta suasana yang sunyi dan nyaman serta yang sesuai dan kondusif untuk pembelajaran yang dapat meningkatkan prestasi akademi, (Marzuki, 1997: 84). Iklim kerja sekolah merupakan suasana yang terdapat di dalam suatu sekolah. Iklim kerja di sekolah menggambarkan keadaan warga sekolah tersebut dalam keadaan riang dan mesra ataupun kepedulian antara satu sama lainnya. Hubungan yang mesra pada iklim kerja di sekolah atau madrasah terjadi karena disebabkan terdapat hubungan yang baik di antara kepala sekolah dan guru, dan diantara guru dan peserta didik (Creemers dan Scheerens, 1994:138).

Iklim kerja di sekolah yang kondusif turut membantu ke arah terwujudnya sekolah yang efektif. Menurut Stol, bahwa iklim sekolah yang positif dan kondusif yang dapat membantu peserta didik berkelakuan baik dan prestasi 
akademinya meningkat (Stol, 1994: 79). Iklim sekolah adalah faktor utama yang menetukan keadaan kualitas pembelajaran yang dihadapi oleh peserta didik di sekolah. Iklim sekolah adalah faktor penting di dalam menentukan efektivitas sekolah, jika efektivitas itu diukur dengan pembelajaran peserta didik dan prestasi akademik yang gemilang.

Secara garis besar iklim sekolah dibagi atas dua kelompok, yaitu iklim terbuka dan iklim tertutup. Hal yang membedakan iklim sekolah terbuka dan tertutup terdiri dari tiga faktor, yaitu: (1) semangat, (2) pertimbangan, dan (3) dorongan atau arah tujuan. Pada iklim sekolah terbuka aspek semangat guru sangat tinggi, aspek pertimbangan dan dorongan yang diberikan oleh pimpinan dan anggota lainnya cukup besar, sehingga mendorong guru dan tenaga pendidikan untuk berprestasi, sedangkan pada iklim sekolah yang tertutup, semangat guru dan pegawai lainnya rendah, juga aspek pertimbangan dan dorongan yang diberikan oleh pimpinan dan teman sejawat (Halpin dan Croft dalam Hoy and Miskel, 1998: 139).

Berdasarkan dua jenis iklim di atas, iklim yang efektif adalah iklim sekolah yang terbuka, karena pada iklim sekolah yang terbuka akan tercipta semangat kerja yang tinggi, guru dan tenaga kependidikan akan mendapatkan kepuasan karena dapat menyelesaikan tugasnya dengan baik, kebutuhan pribadi terpenuhi serta dapat lebih berprestasi sehingga tujuan sekolah dapat tercapai dengan memuaskan. Suatu hasil kajian "mengklasifikasikan iklim kerja di sekolah kepada enam yaitu bermula dari iklim terbuka, autonomus, iklim terkawal, iklim biasa, iklim paternal, dan iklim tertutup, (Halpin \& Croft, dalam Othman, 1990:176).

Menurut Pidarta, iklim kerja yang kondusif di sekolah dipengaruhi pula oleh faktor-faktor sebagai berikut:

(1) penempatan personalia, (2) pembinaan antar hubungan, (3) dinamisasi dan penyelesaian konflik, (4) pemanfaatan informasi, dan (5) peningkatan hubungan kerja. Iklim yang sehat akan tercipta apabila kepala sekolah melakukan hal-hal sebagai berikut: (a) menciptakan lingkungan sekolah yang nyaman yaitu: aman, bersih, sehat, tertib, rindang atau sejuk, dan indah; (b) menciptakan situasi kerja yang kondusif yaitu: keakraban, kebersamaan, semangat kerja yang tinggi, 
kerasan di sekolah; (c) menciptakan ruang kerja yang bersih dan nyaman yaitu: ruang kantor, ruang teori, ruang pabrik, ruang perpustakaan, fasilitas umum/WC, kantin dan lain-lain (Pidarta, 1995: 67).

\section{D.Teori Motivasi}

\section{Teori Abraham H. Maslow}

Salah seorang ilmuwan yang dipandang sebagai pelopor teori motivasi adalah Abraham H. Maslow. Hasil-hasil pemikirannya tertuang dalam bukunya yang berjudul "Motivation and Personality." Teori ini menyatakan bahwa tindakan atau tingkah laku seseorang pada saat tertentu ditentukan oleh kebutuhan yang paling mendesak. Menurut Abraham H.Maslow, ada lima kebutuhan yang tersusun secara hirarki dari yang terendah sampai tertinggi, yang terkenal dengan "Five Needs Hierarchy Theory", yang meliputi:
a) Physiological Needs (Kebutuhan fisik)
b) Safety Needs (Kebutuhan akan rasa aman)
c) Social Needs (Kebutuhan sosial)
d) Esteern Needs (Harga diri)
e) Self Actualization Needs (Memperoleh kebanggaan)

\section{Teori Clayton Alderfer}

Teori ini dikenal pula dengan teori ERG (Existence, Related, Growth Needs). Teori ini mengatakan bahwa berbagai kebutuhan dapat timbul dalam waktu yang bersamaan, namun pada intinya Clayton Alderfer menitik beratkan pada tiga macam kebutuhan, yaitu:

a) Kebutuhan Eksistensi ( $\mathrm{E}=$ Existence), yaitu kebutuhan yang diperlukan demi untuk kelangsungan hidup.

b) Kebutuhan relasi ( $\mathrm{R}=$ Related/relatedness), yaitu kebutuhan untuk berhubungan dengan orang lain.

c) Kebutuhan Pertumbuhan ( $\mathrm{G}=$ Growth $)$, yaitu sebagian dari kebutuhan 


\section{Teori Dua Faktor Herzberg}

Teori ini disebut juga "Motivation-Hygience Theory" atau "Two Factor Theory from Herzberg". Menurut teori ini, yang dimaksud dengan faktor motivasional adalah hal-hal pendorong berprestasi yang sifatnya intrinsik, yang berarti bersumber dari dalam diri seseorang, sedangkan yang dimaksud dengan faktor hygiene atau pemeliharaan, adalah faktor-faktor yang sifatnya ekstrinsik yang berarti bersumber dari luar diri seseorang, misalnya dari organisasi, tetapi turut menentukan perilaku seseorang dalam kehidupannya. Menurut Herzberg, yang tergolong sebagai faktor motivasional antara lain, pekerjaan seseorang, keberhasilan yang diraih, kesempatan bertumbuh, kemajuan dalam karir dan pengakuan terhadap orang lain. Sedangkan faktor-faktor hygiene atau pemeliharaan mencakup antara lain status seseorang dalam organisasi, hubungan seorang guru dan pegawai dengan atasannya, hubungan seseorang dengan rekan-rekan sekerjanya, teknik penyeliaan yang diterapkan oleh para penyelia, kebijaksanaan organisasi, sistem administrasi dalam organisasi kondisi kerja dan sistem imbalan yang berlaku.

\section{Teori Kebutuhan MC Clelland}

Mc.Clelland adalah seorang professor Psikologi pada Universitas Harvard yang juga memberikan kontribusi pemikirannya yang cukup luas tentang teori, motivasi. McClelland mengidentifikasi tiga kebutuhan seseorang di dalam organisasi, yakni antara lain;

a) Kebutuhan akan prestasi. Setiap orang akan berusaha untuk dapat mencapai tujuan yang diinginkan atau ditetapkan lebih efektif dan efisien dibandingkan periode sebelumnya. Dengan demikian maka berarti orang tersebut telah dapat memperbaiki kinerjanya.

b) Kebutuhan akan afiliasi. Setiap orang mempunyai keinginan untuk lebih akrab atau lebih erat dengan orang lain.

c) Kebutuhan akan kekuasaan. Setiap orang ingin mempunyai pengaruh dan dapat mempengaruhi orang lain atau kelompok. 


\section{METODOLOGI PENELITIAN}

Penelitian ini merupakan penelitian explanatory research dengan pendekatan kuantitatif yang menggunakan teknik analisis regresi berganda untuk melihat secara langsung pengaruh beberapa variabel bebas terhadap variabel terikat.

Berdasarkan rumusan permasalahan dan hipotesis yang telah diajukan, maka variabel-variabel yang akan dianalisa terdiri dari dua macam variabel, yaitu variabel bebas $(\mathrm{X})$ atau independent variabel dan variabel terikat $(\mathrm{Y})$ atau dependent variabel.

Variabel bebas (X) yang digunakan dalam penelitian ini terdiri atas beberapa variabel yaitu:

1. Variabel X1, adalah variabel pemahaman kurikulum.

2. Variabel X2, adalah variabel iklim kerja.

3. Variabel X3, adalah variabel motivasi.

Variabel terikat (Y) yang akan dikaji dalam penelitian ini adalah kinerja guru pada SMK YPM 12 Tuban. Objek dalam penelitian ini melibatkan seluruh guru sebagai responden. Sementara itu, metode yang digunakan adalah metode sampling yakni dengan metode sensus. Penggunaan metode sensus dilandasi pada pertimbangan bahwa jumlah sampel dianggap tidak terlalu banyak dan peneliti dianggap mampu untuk melaksanakannya (Sugiono, $2001: 62$ ).

\section{HASIL}

\section{Analisis Regresi Linier Berganda}

Dalam pengolahan data menggunakan analisis regresi linier berganda, diperoleh hasil seperti gambar tabel di bawah ini;

Tabel 1. Hasil Analisis Regresi

\begin{tabular}{|l|l|l|l|l|l|}
\hline $\begin{array}{l}\text { Variabel } \\
\text { Dependen }\end{array}$ & $\begin{array}{l}\text { Variabel } \\
\text { Independen }\end{array}$ & $\mathbf{B}$ & $\mathbf{t}_{\text {hitung }}$ & Signifikan & Keterangan \\
\hline \multirow{4}{*}{$\begin{array}{l}\text { Kinerja } \\
\text { Guru }\end{array}$} & Konstanta & 0,944 & & & \\
\cline { 2 - 6 } & Pemahaman & 0,245 & 3,908 & 0,000 & Signifikan \\
\cline { 2 - 6 } & Kurikulum & 0,351 & 4,734 & 0,000 & Signifikan \\
\cline { 2 - 6 } & Motivasi Kerja & 0,407 & 6,560 & 0,000 & Signifikan \\
\cline { 2 - 6 } & & &
\end{tabular}




\begin{tabular}{|ll|}
\hline$\square$ & $=0,050$ \\
$\mathrm{R}$ & $=0,849$ \\
Koefisien Determinasi (Adj. R $\left.{ }^{2}\right)$ & $=0,708$ \\
F-hitung & $=56,815$ \\
Signifikansi & $=0,000$
\end{tabular}

Berdasarkan tabel di atas, diperoleh model regresi hubungan pemahaman, kurikulum, iklim kerja, serta motivasi terhadap kinerja guru. Seperti penjelasan hasil tabel di bawah ini:

$$
Y=0,944+0,245 X_{1}+0,351 X_{2}+0,407 X_{3}
$$

Sementara itu, interpretasi model regresi diperoleh hasil seperti di bawah ini:

$$
\beta_{1}=0,245
$$

Koefisien regresi di atas, menunjukkan bahwa apabila terdapat kenaikan skala tanggapan responden sebanyak 1 kali pada $\mathrm{X}_{1}$ dan variabel yang lain dianggap tetap atau tidak ada perubahan sama sekali, maka akan terjadi peningkatan pada variabel Y sebesar 0,245. Dapat dilihat bahwa koefisien yang diperoleh bernilai positif, jadi apabila terjadi peningkatan pada $X_{1}$, maka $Y$ akan meningkat, dan sebaliknya apabila $X_{1}$ menurun, maka akan terjadi penurunan pada Y.

$$
\boldsymbol{\beta}_{2}=\mathbf{0 , 3 5 1}
$$

Koefisien regresi ini menunjukkan bahwa apabila terdapat kenaikan skala tanggapan responden sebanyak 1 kali pada $X_{2}$ dan variabel yang lain dianggap tetap atau tidak ada perubahan sama sekali, maka akan terjadi peningkatan pada variabel Y sebesar 0,351. Dapat dilihat bahwa koefisien yang diperoleh bernilai positif, jadi apabila terjadi peningkatan pada $\mathrm{X}_{2}$, maka $\mathrm{Y}$ akan meningkat, dan sebaliknya apabila $\mathrm{X}_{2}$ menurun, maka akan terjadi penurunan pada $\mathrm{Y}$.

$$
\boldsymbol{\beta}_{\mathbf{1}}=\mathbf{0 , 4 0 7}
$$

Koefisien regresi ini menunjukkan bahwa apabila terdapat kenaikan skala tanggapan responden sebanyak 1 kali pada $X_{3}$ dan variabel yang lain dianggap tetap atau tidak ada perubahan sama sekali, maka akan terjadi peningkatan pada variabel Y sebesar 0,407. Dapat dilihat bahwa koefisien yang diperoleh bernilai 
positif, jadi apabila terjadi peningkatan pada $\mathrm{X}_{3}$, maka $\mathrm{Y}$ akan meningkat, dan sebaliknya apabila $\mathrm{X}_{3}$ menurun, maka akan terjadi penurunan pada $\mathrm{Y}$.

\section{Koefisien Determinasi}

Koefisien determinasi $\left(R^{2}\right)$ adalah ukuran ketepatan atau kecocokan garis regresi. Selain itu, $R^{2}$ juga dapat digunakan untuk mengukur besar proporsi keragaman total yang dapat dijelaskan oleh garis regresi.

Tabel 2. Koefisien Determinasi

\begin{tabular}{|l|l|}
\hline $\mathbf{R}$ & Adjusted R Square \\
\hline 0.849 & 0.708 \\
\hline
\end{tabular}

Hasil tersebut menjelaskan sumbangan atau kontribusi dari variabelvariabel bebas yang disertakan dalam persamaan regresi dalam menjelaskan keragaman variabel $\mathrm{Y}$, adalah sebesar 70,8 \%, sedangkan 29,2 \% lainnya disumbangkan oleh variabel lainnya yang tidak dimasukkan ke dalam persamaan ini.

\section{Uji F}

Uji F dilakukan untuk menunjukkan apakah semua variabel yang digunakan dalam model regresi memiliki pengaruh yang signifikan terhadap $\mathrm{Y}$ atau untuk mengukur ketepatan model regresi.

Hipotesis yang digunakan dalam pengujian adalah sebagai berikut :

$\mathrm{H}_{0}: \beta_{i}=0$ (tidak terdapat pengaruh yang signifikan antara variabel $\mathrm{X}_{1}, \mathrm{X}_{2}$, dan $\mathrm{X}_{3}$ terhadap $\mathrm{Y}$ )

$\mathrm{H}_{\mathrm{a}}: \beta_{i} \neq 0$ (terdapat pengaruh yang signifikan antara variabel $\mathrm{X}_{1}, \mathrm{X}_{2}$, dan $\mathrm{X}_{3}$ terhadap $\mathrm{Y}$ )

Setelah dilakukan olah data, diperoleh nilai $\mathrm{F}_{\text {hitung }}$ sebesar 56,815 dan didapatkan nilai signifikansi sebesar 0,000. Dapat dilihat bahwa nilai signifikansi kurang dari 0,05 . Sehingga diambil keputusan $\mathrm{H}_{0}$ ditolak pada taraf $\alpha=5 \%$. Sehingga disimpulkan bahwa terdapat pengaruh yang signifikan antara variabel $\mathrm{X}_{1}, \mathrm{X}_{2}$, dan $\mathrm{X}_{3}$ terhadap $\mathrm{Y}$ atau model regresi yang terdiri atas variabel $\mathrm{X}_{1}, \mathrm{X}_{2}$, dan $\mathrm{X}_{3}$ telah tepat digunakan. 


\section{Uji t}

Uji t digunakan untuk mengetahui apakah masing-masing variabel bebas pembentuk model regresi memiliki pengaruh yang signifikan terhadap Y. Variabel bebas pembentuk model regresi disimpulkan berpengaruh signifikan jika signifikansi $<0,05$. Pengujian variabel-variabel tersebut secara parsial adalah sebagai berikut :

Tabel 3. Uji t

\begin{tabular}{|l|l|l|l|}
\hline Variabel Independen & $\mathbf{t}_{\text {hitung }}$ & Signifikan & Keterangan \\
\hline Pemahaman Kurikulum & 3,908 & 0,000 & Signifikan \\
\hline Iklim Kerja & 4,734 & 0,000 & Signifikan \\
\hline Motivasi & 6,560 & 0,000 & Signifikan \\
\hline
\end{tabular}

\section{a. Variabel $\mathbf{X}_{1}$ (Pemahaman Kurikulum)}

Hipotesis uji yang digunakan adalah:

$\mathrm{H}_{0}: \beta_{1}=0$ (variabel $\mathrm{X}_{1}$ tidak berpengaruh signifikan terhadap $\mathrm{Y}$ )

$\mathrm{H}_{\mathrm{a}}: \beta_{1} \neq 0$ (variabel $\mathrm{X}_{1}$ berpengaruh signifikan terhadap $\mathrm{Y}$ )

Berdasarkan tabel 3. Uji t diperoleh signifikansi sebesar 0,000. Nilai tersebut lebih kecil daripada 0,05. Pengujian ini menunjukkan bahwa $\mathrm{H}_{0}$ ditolak sehingga disimpulkan bahwa $X_{1}$ (Pemahaman Kurikulum) berpengaruh signifikan terhadap Y (Kinerja Guru).

\section{b. Variabel $\mathrm{X}_{2}$ (Iklim Kerja)}

Hipotesis uji yang digunakan adalah:

$\mathrm{H}_{0}: \beta_{2}=0$ (variabel $\mathrm{X}_{2}$ tidak berpengaruh signifikan terhadap $\mathrm{Y}$ )

$\mathrm{H}_{1}: \beta_{2} \neq 0$ (variabel $\mathrm{X}_{2}$ berpengaruh signifikan terhadap $\mathrm{Y}$ )

Berdasarkan tabel 3. Uji t diperoleh signifikansi sebesar 0,000. Nilai tersebut lebih kecil daripada 0,05. Pengujian ini menunjukkan bahwa $\mathrm{H}_{0}$ ditolak sehingga disimpulkan bahwa $\mathrm{X}_{2}$ (Iklim Kerja) berpengaruh signifikan terhadap Y (Kinerja Guru).

\section{c. Variabel $\mathbf{X}_{3}$ (Motivasi)}

Hipotesis uji yang digunakan adalah:

$\mathrm{H}_{0}: \beta_{3}=0$ (variabel $\mathrm{X}_{3}$ tidak berpengaruh signifikan terhadap $\mathrm{Y}$ )

$\mathrm{H}_{\mathrm{a}}: \beta_{3} \neq 0$ (variabel $\mathrm{X}_{3}$ berpengaruh signifikan terhadap $\mathrm{Y}$ ) 
Berdasarkan tabel 3. Uji t, diperoleh signifikansi sebesar 0,000. Nilai tersebut lebih kecil daripada 0,05. Pengujian ini menunjukkan bahwa $\mathrm{H}_{0}$ ditolak sehingga disimpulkan bahwa $\mathrm{X}_{3}$ (Motivasi Kerja) berpengaruh signifikan terhadap Y (Kinerja Guru).

\section{Dominan}

Untuk menentukan variabel bebas paling berpengaruh terhadap Y, dilakukan dengan membandingkan koefisien regresi terstandarisasi $(\beta)$ antara variabel yang satu dengan yang lain. Variabel yang paling dominan pengaruhnya terhadap $\mathrm{Y}$ adalah variabel yang memiliki koefisien regresi terstandarisasi yang paling besar.

Untuk membandingkan koefisien regresi masing-masing variabel bebas, disajikan tabel peringkat sebagai berikut:

Tabel 4. Ringkasan Hasil Analisis Regresi

\begin{tabular}{|l|l|l|l|}
\hline Variabel & Peringkat & Koefisien Standardized $(\boldsymbol{\beta})$ & Pengaruh \\
\hline $\mathrm{X}_{1}$ & 3 & 0,271 & Signifikan \\
\hline $\mathrm{X}_{2}$ & 2 & 0,352 & Signifikan \\
\hline $\mathrm{X}_{3}$ & 1 & 0,485 & Signifikan \\
\hline
\end{tabular}

Berdasarkan pada tabel 4. Ringkasan hasil analisis regresi di atas, variabel $X_{3}$ (Motivasi) merupakan variabel yang memiliki koefisien regresi terstandarisasi paling besar. Hal ini menunjukkan bahwa Y (Kinerja Guru) lebih banyak dipengaruhi oleh variabel $\mathrm{X}_{3}$ (Motivasi) dibandingkan variabel-variabel lain, sehingga disimpulkan variabel Motivasi merupakan variabel paling dominan. Koefisien yang dimiliki oleh variabel Selain itu, koefisien regresi variabel Motivasi bertanda positif yang berarti jika terjadi peningkatan Motivasi maka terjadi peningkatan pada Kinerja Guru dan sebaliknya jika terjadi penurunan pada Motivasi maka terjadi penurunan pula pada Kinerja Guru.

\section{PEMBAHASAN}

\section{Pengaruh Pemahaman kurikulum (X1) terhadap kinerja guru (Y)}

Berdasarkan olah data diperoleh signifikansi $\mathrm{T}$ hitung 3 , 908. $\mathrm{Dg}$ signifikasi sebesar 0,000 . Nilai tersebut lebih kecil daripada 0,05. Pengujian ini menunjukkan bahwa H0 ditolak sehingga disimpulkan bahwa X1 (Pemahaman 
Kurikulum) berpengaruh signifikan terhadap Y (Kinerja Guru). Berarti variabel pemahaman kurikulum berpengaruh secara parsial terhadap kinerja guru.

\section{Pengaruh iklim kerja (X2) terhadap kinerja guru (Y)}

Berdasarkan olah data diperoleh signifikansi $\mathrm{T}$ hitung 4,734. Dg signifikasi sebesar 0,000. Nilai tersebut lebih kecil daripada 0,05. . Pengujian ini menunjukkan bahwa H0 ditolak sehingga disimpulkan bahwa X2 (Iklim Kerja) berpengaruh signifikan terhadap Y (Kinerja Guru). Berarti ada pengaruh secara parsial variabel iklim kerja (X2) terhadap kinerja guru.(Y).

\section{Pengaruh Motivasi (X3) terhadap kinerja guru.(Y)}

Berdasarkan olah data diperoleh signifikansi $\mathrm{T}_{\text {hitung }}$ 6,560. Dg signifikasi sebesar 0,000. Nilai tersebut lebih kecil daripada 0,05. Pengujian ini menunjukkan bahwa H0 ditolak sehingga disimpulkan bahwa X3 (Motivasi Kerja) berpengaruh signifikan terhadap Y (Kinerja Guru).berarti ada pengaruh secara parsial variabel motivasi (X3) terhadap kinerja guru (Y).

\section{Pengaruh secara bersama-sama X1, X2 dan X3 terhadap $Y$}

Pasca dilakukan olah data, diperoleh nilai Fhitung sebesar 56,815 dan didapatkan nilai signifikansi sebesar 0,000. Dapat dilihat bahwa nilai signifikansi kurang dari 0,05. Sehingga diambil keputusan H0 ditolak pada taraf $\alpha=5 \%$. Sehingga disimpulkan bahwa terdapat pengaruh yang signifikan antara variabel $\mathrm{X} 1$, X2, dan X3 terhadap $\mathrm{Y}$ berarti terdapat pengaruh secara bersama sama varibael pemahaman kurikulum (X1), iklim kerja(X2) dan motivasi(X3) terhadap kinerja guru (Y).

\section{PENUTUP}

\section{Kesimpulan}

Hasil penelitian menunjukkan bahwa terdapat pengaruh positif antara variabel bebas pemahaman kurikulum (X1), iklim kerja (X2) dan motivasi (X3) terhadap kinerja Guru (Y) pada SMK YPM 12 Tuban. Hal ini ditunjukkan oleh besarnya korelasi (r) 0,708 karena nilai "r" memiliki tanda positif dengan variabel Y, adalah sebesar 70,8 \%, sedangkan 29,2 \% lainnya disumbangkan oleh variabel lainnya yang tidak dimasukkan ke dalam persamaan ini. Serta diperoleh model regresi $\mathrm{Y}=0,944+0,245 \mathrm{X} 1+0,351 \mathrm{X} 2+0,407 \mathrm{X} 3$. Pasca dilakukan olah data, 
diperoleh nilai Fhitung sebesar 56,815 dan didapatkan nilai signifikansi sebesar 0,000. Dapat dilihat bahwa nilai signifikansi kurang dari 0,05. Sehingga diambil keputusan $\mathrm{H} 0$ ditolak pada taraf $\alpha=5 \%$. Sehingga disimpulkan bahwa terdapat pengaruh simultan yang signifikan antara variabel X1, X2, dan X3 terhadap Y.

Secara parsial variabel bebas pemahaman kurikulum (X1), iklim kerja (X2) dan motivasi (X3) terhadap Kinerja Guru (Y) pada SMK YPM 12 Tuban, diperoleh T hitung untuk Pemahaman Kurikulum (X1) sebesar 3,903. Iklim kerja (X2) Sebesar 4,734 dan Motivasi (X3) sebesar 6,560 (kesemuanya lebih besar dari Ttabel 1,658.) Variabel bebas pembentuk model regresi di simpulkan berpengaruh signifikan jika signifikasi $<0,05$. Berdasar hasil perhitungan tersebut terdapat pengaruh secara parsial antara variabel $\mathrm{X} 1$ terhadap $\mathrm{Y}, \mathrm{X} 2$ terhadap $\mathrm{Y}$ dan $\mathrm{X} 3$ terhadap Y.

\section{Saran}

Sekolah sebagai sebuah institusi profesi intelektual seperti halnya SMK YPM 12 Tuban, harus melakukan workshop untuk pembinaan skill, serta outbond sebagai wahana untuk merekatkan suasana iklimkerja yang kondusif dan memberikan pelatihan dan pendampingan komunikasi dalam melatih motivasi sebagai guru yang kompeten dan professional.

\section{DAFTAR RUJUKAN}

Djalil, A. 2003. Pendidikan Berkualitas Melalui Sekolah Yang Efektif dan Berkembang. Dalam Dum Andriani, dkk.

Hamalik, O. 1995. Kurikulum dan Pembelajaran. Jakarta: Bumi Aksara.

Hamzah, B. Uno. 2013. Teori Motivasi dan Pengukurannya, Jakarta. Bumi Aksara

Hadi, Sutrisno.2000. Metodologi Research. Yogyakarta: Andi

Kunandar. 2007. Guru Profesional. Jakarta: Rajawali Pers.

Marzuki. S. 1997. Kajian Sekolah Berkesan di Malaysia: Model Lima Faktor oleh. Kuala Lumpur: University Malaya. Disertasi Tidak Diterbitkan.

Mulyono, Tj dan Soetjipto, R. 1982. Ilmu Pengetahuan Sosial. Jakarta: Departemen Pendidikan dan Kebudayaan.

Mutis, T. 1995. Pendekatan Ekonomi Pengetahuan dalam Manajemen Kodeterminasi: Jurus Jitu Memenangkan Persaingan. Jakarta: Grasindo. 
Nash, M. 1983. Managing Organization Performance. San Francisco: Jossey Bass Publisher.

Owens, R.G., 1991. Organizational Behavior in Education. Toronto: Allyn Bacon, $4^{\text {th }}$ Edition.

Pidarta, M. 1995. Peranan Sekolah Pada Pendidikan Dasar, Jakarta: Gramedia.

Othman, R. 1990. Satu Kajian Mengenai Iklim Sekolah Menengah di Daerah Temerloh. Tesi Sarajan Pendidikan. Fakulti Pendidikan Universiti Malaya: Kuala Lumpur.

Ruky, A. S. 2002. Sistem Manajemen Kinerja. Jakarta: Quantum Teaching.

Riduwan,2003. Dasar-Dasar Statistika. Bandung. Alfabeta

Supardi, 2013. Kinerja Guru. Jakarta: Rajagrafindo

Siagian, S. P. 2002. Kiat Meningkatkan Produktivitas Kerja. Jakarta: Rineka Cipta.

Sugiyono, 2010. Statistika Untuk Penelitian. Bandung: Alfabeta 